\title{
Haematological, Serum Biochemical and Histological Responses of Cockerels to Long Term Consumption of Telfairia occidentalis Leaves Extract
}

\author{
Temitope Oyekemi Onyekwereh ${ }^{1}$, David Olusoji Adejumo ${ }^{1}$, Kolawole Daniel Afolabi*², Friday Chima Nworgu ${ }^{3}$ \\ and Adenekan, Olusola Olubisi ${ }^{1}$ \\ ${ }^{1}$ Animal Physiology Laboratory, Department of Animal Science, University of Ibadan, Ibadan, Nigeria \\ ${ }^{2}$ Department of Animal Science, University of Uyo, Uyo, Nigeria \\ ${ }^{3}$ Federal College of Animal Health and Production Technology, IAR\&T, Moor Plantation, Ibadan, Nigeria \\ *Corresponding author`s Email: kaydafl@yahoo.com
}

Received: 14 Feb 2019

Accepted: 18 Mar 2019

\begin{abstract}
Haematological, serum biochemical and haematological histological responses were studied in cockerels undergoing a long-term supplementation with Telfairia occidentalis Leave Extract (TOLE). Haematological and serum biochemical parameters investigated included haemoblobin, white blood cells, red blood cells, lymphocytes, heterophils, monocytes, eosinophils, total protein, aspartate aminotransferase, aspartate amino transferase and triglyceride. Histological changes associated with Telfairia occidentalis leaves extract on the kidney, liver, spleen and testes were also examined. Result showed that birds on TOLE has higher values for most of the haematological parameters studied which were significantly $(\mathrm{P}<0.05)$ higher than the control. Also the total protein, globulin and alanine aminotransferase were significant $(\mathrm{P}<0.05)$ for birds on TOLE having higher values while for triglycerides birds on the control treatment had the higher values which was significant. There were no significant changes in the albumin and aspayrtate aminotransferase. Histological changes showed mild to severe congestion in the spleen and testes of birds that received 120 and $150 \mathrm{~mL}$ TOLE/L of water that also showed reduced germinal epithelium height and sloughing of the germinal epithelium respectively. Long term supplementation of TOLE for cockerel production should not exceed $60 \mathrm{~mL}$ of TOLE per liter of water as the administration in excess of this can bring about tissue breakdown and reduced fertility. Animals suffering from blood loss can benefit from the administration of fluted pumpkin leaves extract as the extract increased erythron production.
\end{abstract}

Key wordS: Cockerels, Haematology, Serum biochemistry, Organ histology, Telfairia occidentalis, leaf extract

\section{INTRODUCTION}

Nigeria has rich genetic resources of cultivated semi wide and wild species of crops being used as traditional vegetables and different types are consumed by the various ethnic groups for different reasons (Fasuyi, 2006).

Nigeria has a wide range of savannah, tropical rain forest to coastal swampy vegetation where different permanent and arable crops are grown. Different fruits, vegetables and spices are also grown, that vary across localities as they are favorite delicacies and sources of vitamins, minerals and medicine (Fasuyi, 2006) in their diets. Telferia occidentalis is one of these vegetables that is commonly grown and eaten from the coastal area to other parts of the country (Imosemi, 2018). Regular consumption of these plant foods are associated with numerous health benefits rooted in their various physiological and nutritional constituents (Imosemi, 2018; Jimoh, 2018; Hunter and Fletcher, 2002). Plant leaf meal can offer a good alternative to synthetic drugs because they are cheap, readily available, safe, economical and biodegradable (Nneka, 2006). Telfairia occidentalis (fluted pumpkin) is a tropical vine grown in West Africa and highly reputed in traditional medicine (Badifu et al., 1995; Badifu et al., 1995). Telfairia occidentalis contains nutrients such as protein, carbohydrate, vitamins minerals and fibre (Fasuyi, 2006). It also contains oxalate, saponins, glycosides, flavonoids alkaloids and resins (Imosemi, 2018; Jimoh, 2018; Akubue et al., 1980). The nutritional content of $T$. occidentalis makes it desirable as dietary 
supplements for humans. The diet preparation of air dried leaves of the plant significantly increased red blood cells counts, white blood cells packed cell volume and haemoblobin concentration in rats (Alada, 2000) while the dietary preparation made with sun dried leaves had no significant effect on haematological parameters in broilers (Fasuyi and Nonyerem, 2007), indicating that the potency of the plant depends on the method of preparation of the plant for consumption. Adaramoye et al. (2007) reported that $T$. occidentalis leaves have hypolipidemic effect and may be a useful therapy in hypercholesterolemia. It was found out that aqueous and ethanol extract of $T$. occidentalis could salvage and prevent free radical production and at the same time have antimicrobial properties (Oboh et al., 2010). In spite of the widespread use of $T$. occidentalis, there are scanty information on its various biological effects on cockerels. This study investigated haematological parameters, serum biochemical indices and histological changes of some organs associated with long term administration of $T$. occidentalis Leaves Extract (TOLE) on cockerels.

\section{MATERIALS AND METHODS}

Preparation of Telfairia occidentalis leaves extract

A kilogram of freshly cut TOLE with leaf stalks were washed, drained, chopped and pounded in mortar and pestle. This was then squeezed and filtered with cheese cloth to obtain a homogenous extract of the T. occidentalis leaf extract (Nworgu et al., 2007). The extract was prepared at four days' interval and served to the birds fresh according to the treatments.

\section{Experimental animals and management}

A total of one hundred and sixty-two (162) Nera black cockerel chicks were weighed and randomly allotted to six dietary treatments that contains $30,60,90,120$ and $150 \mathrm{~mL}$ TOLE per one liter of water (Nworgu et al., 2007) for B, C, D, E and F respectively. Treatment A served as the control with no extract. Each treatment was replicated three times with nine birds per replicate in a completely randomized design. The experiment lasted for 24 weeks. The birds were fed the same diets for the first eight weeks and later grower diet was given to the birds till the end of the experiment. The TOLE supplement was served at four days interval throughout the period of the experiment according to the treatment per liter of water and later clean water was served. Feed and water were served ad-libitum. Both the feed intake and weight gain were monitored. Other management practices such as routine vaccination, drug administration and maintenance of cleanliness within and outside the poultry houses were observed.

\section{Collection of blood samples}

Blood samples were collected at 24th week of the experiment. Six birds per treatment were randomly selected and bled via wing veins, for haemoglobin and serum biochemical analysis Serum was obtained by centrifugation and the serum samples were stored in deep freezers at minus $10^{\circ} \mathrm{c}$ until analyzed.

\section{Heamatological analysis}

The Packed Cell Volume (PCV), Red Blood Cell (RBC), White Blood Cell (WBC) and Haemoglobin ( $\mathrm{Hb}$ ) concentration were determined using the Wintrobe Microhematocrit, Improved Neubauer haemocytometer and Cyanmethemoglobin methods, respectively (Coles, 1986). Mean Corpuscular Haemoglobin (MCH), Mean Corpuscular Volume (MCV) and Mean Corpuscular Haemoglobin Concentration (MCHC) levels were computed using the formula described by Jain (1986).

$$
\begin{aligned}
& \mathrm{MCH}=\frac{\text { Haemoglobin } \times 10}{\mathrm{RBC}} \\
& \mathrm{MCV}=\frac{\mathrm{PCV} \times 10}{\mathrm{RBC}} \\
& \mathrm{MCHC}=\frac{\text { Haemoglobin } \times 100}{\mathrm{PCV}}
\end{aligned}
$$

\section{Serum biochemical analysis}

The serum biochemical assays were carried out using the standard chemical procedures. Total serum protein by Goldberg refractometer (Kohn and Allen, 1995), albumen by Bromocresol Green (BCG) method (Peters et al., 1982) while globulin was calculated according to Coles (1986). Alanine Aminotransferase (ALT), Aspartate Aminotransferase (AST) and triglyceride were determined using Randox test kits (Randox Laboratiries Crumlin, County Antrim, United Kingdom).

\section{Histological studies}

Histological studies of the organs and tissues were done according to procedures described by Disbrey and Rack (1970) and Drury and Wallington (1967). The kidneys, liver, spleen and testes of the cockerel were removed from the surrounding tissues. They were fixed in $10 \%$ formal saline, and after 72 hours the organs were dehydrated in graded alcohol (20,30, 50, 70 and 95\%) for five minutes, cleared in xylene and embedded in paraffin. The resulting blocks were completely sectioned and randomized. The selected sections were stained in haemotoxylin and eosin and the slides were examined at magnification of $x 400$ under light or optical microscope. 


\section{Ethical approval}

The study was conducted after approval of ethic and research committee of the Department of Animal Science, University of Ibadan, Ibadan, Nigeria.

\section{Data analysis}

The mean values obtained for the determination of various indices in respect of the six treatments were subjected to one-way analysis of variance (SAS, 2003). Treatment means were also separated by Duncan option of the software at $\mathrm{p}=0.05$ (5\% significant level).

\section{RESULTS}

Data on the effects of TOLE on haematological parameters and serum biochemical constituents of cocks are presented in tables 2 and 3 respectively. The RBC, lymphocytes, heterophils, albumin, and AST values were similar $(\mathrm{P}>0.05)$ among the various treatment groups, while the $\mathrm{PVC}, \mathrm{Hb}, \mathrm{WBC}, \mathrm{MCV}, \mathrm{MCH}, \mathrm{MCHC}$, monocytes and Eosinophils were statistically different $(\mathrm{P}<0.05)$ across the treatments. Except for albumin and AST, all other serum parameters investigated were significantly $(\mathrm{P}<0.05)$ affected by the administration of the TOLE. For histopathological examination, there were lesion/necrosis in the liver and kidney of cocks on TOLE treatments while the spleen and testes did not show any visible lesion in all the treatments. However, for birds served $120 \mathrm{~mL}$ and $150 \mathrm{~mL}$ TOLE/L of water there were reduced germinal epithelia heights and sloughing of the germinal epithelia respectively (Table 4).

Table 2. Haematological response of Nera black cockerels served Telfairia occidentalis leaves extract at 4 weeks interval for 24 weeks

\begin{tabular}{|c|c|c|c|c|c|c|c|}
\hline $\begin{array}{l}\text { Treatments } \\
\text { Level of TOLE }\end{array}$ & $\begin{array}{c}\mathrm{A} \\
\mathbf{0} \mathrm{ml}\end{array}$ & $\begin{array}{c}\text { B } \\
30 \mathrm{ml} / \mathrm{l}\end{array}$ & $\begin{array}{c}\mathrm{C} \\
60 \mathrm{ml} / \mathrm{l}\end{array}$ & $\begin{array}{c}\text { D } \\
90 \mathrm{ml} / \mathrm{l}\end{array}$ & $\begin{array}{c}E \\
120 \mathrm{ml} / \mathrm{l}\end{array}$ & $\begin{array}{c}F \\
150 \mathrm{ml} / \mathrm{l}\end{array}$ & SEM \\
\hline$\overline{\mathrm{PCV}(\%)}$ & $35.20^{\mathrm{d}}$ & $37.22^{\mathrm{ab}}$ & $38.39^{\mathrm{a}}$ & $35.53^{\mathrm{dc}}$ & $36.58^{\mathrm{bcd}}$ & $37.11^{\mathrm{abc}}$ & 0.14 \\
\hline $\mathrm{Hb}(\mathrm{g} / \mathrm{dL})$ & $11.73^{\mathrm{c}}$ & $12.41^{\mathrm{bc}}$ & $12.79^{\mathrm{a}}$ & $11.84^{\mathrm{bc}}$ & $12.28^{\mathrm{abc}}$ & $12.63^{\mathrm{a}}$ & 0.05 \\
\hline WBC $\left(\times 10^{6} / \mathrm{mm}^{3}\right)$ & $13.24^{\mathrm{ab}}$ & $12.45^{\mathrm{bc}}$ & $13.34^{\mathrm{ab}}$ & $13.92^{\mathrm{a}}$ & $12.16^{\mathrm{c}}$ & $13.55^{\mathrm{a}}$ & 0.06 \\
\hline $\operatorname{MCHC}(\%)$ & $33.33^{\mathrm{a}}$ & $33.19^{\mathrm{ab}}$ & $32.97^{b}$ & $33.33^{\mathrm{a}}$ & $33.33^{\mathrm{a}}$ & $33.33^{\mathrm{a}}$ & 0.21 \\
\hline Lymphocytes (\%) & 65.50 & 60.55 & 63.19 & 65.43 & 64.83 & 67.80 & 0.89 \\
\hline Heterophils (\%) & 29.00 & 35.36 & 30.36 & 28.33 & 29.52 & 31.33 & 0.87 \\
\hline Monocytes (\%) & $2.66^{\mathrm{abc}}$ & $2.86^{\mathrm{abc}}$ & $2.14^{\mathrm{c}}$ & $3.88^{\mathrm{a}}$ & $3.51^{\mathrm{ab}}$ & $2.28^{\mathrm{bc}}$ & 0.10 \\
\hline
\end{tabular}

Table 3. Serum biochemical response of Nera black cockerels served Telfairia occidentalis leaves extract at 4 weeks interval for 24 weeks

\begin{tabular}{|c|c|c|c|c|c|c|c|}
\hline $\begin{array}{l}\text { Treatments/ } \\
\text { Level of TOLE }\end{array}$ & $\begin{array}{c}\mathrm{A} \\
\mathbf{0} \mathrm{ml} / \mathrm{l} \\
\end{array}$ & $\begin{array}{c}\text { B } \\
30 \mathrm{ml} / \mathrm{l} \\
\end{array}$ & $\begin{array}{c}\mathrm{C} \\
60 \mathrm{ml} / \mathrm{l} \\
\end{array}$ & $\begin{array}{c}D \\
90 \mathrm{ml} / \mathrm{l}\end{array}$ & $\begin{array}{c}E \\
120 \mathrm{ml} / \mathrm{l}\end{array}$ & $\begin{array}{c}F \\
150 \mathrm{ml} / \mathrm{l}\end{array}$ & SEM \\
\hline Total protein $(\mathrm{g} / \mathrm{dL})$ & $3.88^{\mathrm{b}}$ & $4.24^{\mathrm{ab}}$ & $4.84^{\mathrm{ab}}$ & $4.97^{\mathrm{a}}$ & $4.98^{\mathrm{a}}$ & 4.26 & 0.08 \\
\hline Albumen $(\mathrm{g} / \mathrm{dL})$ & 2.14 & 2.18 & 2.37 & 2.30 & 2.08 & 2.04 & 0.03 \\
\hline Globulin (g/dL) & $1.61^{\mathrm{b}}$ & $2.06^{\mathrm{ab}}$ & $2.48^{\mathrm{ab}}$ & $2.67^{\mathrm{a}}$ & $2.91^{\mathrm{a}}$ & $2.08^{\mathrm{ab}}$ & 0.07 \\
\hline Albumin/globulin ratio & $1.44^{\mathrm{a}}$ & $1.01^{\mathrm{b}}$ & $0.98^{\mathrm{b}}$ & $0.93^{\mathrm{b}}$ & $0.75^{\mathrm{b}}$ & $1.02^{\mathrm{b}}$ & 0.02 \\
\hline Aspartate amino transferase (IU/L) & 91.60 & 102.40 & 101.86 & 97.28 & 94.86 & 96.10 & 1.28 \\
\hline Alanine amino transferase (IU/L) & $7.96^{\mathrm{bc}}$ & $7.74^{\mathrm{c}}$ & $8.41^{\mathrm{ab}}$ & $8.00^{\mathrm{abc}}$ & $7.84^{\mathrm{bc}}$ & $8.06^{\mathrm{a}}$ & 0.05 \\
\hline Triglyceride (mg/dL) & $202.84^{\mathrm{a}}$ & $163.57^{b}$ & $160.52^{\mathrm{b}}$ & $149.42^{\mathrm{b}}$ & $158.62^{\mathrm{b}}$ & $154.92^{\mathrm{b}}$ & 1.54 \\
\hline
\end{tabular}

${ }^{\mathrm{abc}}$ Means in the same row with different superscript are significantly $(\mathrm{P}<0.05)$ different. SEM=Standard error of means 
Table 4. Histopathological effects of Telfairia occidentalis leaves extract served at 4 weeks interval for 24 weeks to Nera black cockerels on internal organs

\begin{tabular}{|c|c|c|c|c|c|c|}
\hline $\begin{array}{l}\text { Treatments } \\
\text { Organs } \\
\end{array}$ & $\begin{array}{c}\text { A } \\
0 \text { TOLE } \\
(\mathrm{mL} / \mathrm{L}) \\
\end{array}$ & $\begin{array}{c}\text { B } \\
30 \text { TOLE } \\
(\mathrm{mL} / \mathrm{L}) \\
\end{array}$ & $\begin{array}{c}\text { C } \\
60 \text { TOLE } \\
(\mathrm{mL} / \mathrm{L}) \\
\end{array}$ & $\begin{array}{c}\text { D } \\
90 \text { TOLE } \\
(\mathrm{mL} / \mathrm{L}) \\
\end{array}$ & $\frac{E}{120}$ TOLE $(\mathrm{mL} / \mathrm{L})$ & $\begin{array}{c}\text { F } \\
150 \text { TOLE }(\mathrm{mL} / \mathrm{L})\end{array}$ \\
\hline Kidney & $\begin{array}{l}\text { No visible } \\
\text { lesion }\end{array}$ & $\begin{array}{l}\text { Wide spread } \\
\text { coagulative } \\
\text { necrosis of renal } \\
\text { tubules }\end{array}$ & $\begin{array}{c}\text { Severe } \\
\text { generalized } \\
\text { interstitial } \\
\text { congestion. }\end{array}$ & $\begin{array}{l}\text { Mild moderate loss } \\
\text { and sloughing of renal } \\
\text { tubular epithelium }\end{array}$ & $\begin{array}{l}\text { Severe generalized } \\
\text { interstitial congestion }\end{array}$ & $\begin{array}{l}\text { Widespread } \\
\text { coagulative necrosis } \\
\text { of the renal tubules }\end{array}$ \\
\hline Liver & $\begin{array}{l}\text { No visible } \\
\text { lesion }\end{array}$ & Portal congestion & $\begin{array}{l}\text { Severe central } \\
\text { venous } \\
\text { congestion }\end{array}$ & $\begin{array}{c}\text { Severe portal } \\
\text { congestion with } \\
\text { periportal cellular } \\
\text { infiltration by mono- } \\
\text { nucleus cell }\end{array}$ & $\begin{array}{c}\text { Severe portal } \\
\text { congestion with } \\
\text { periportal cellular } \\
\text { infiltration by mono- } \\
\text { nucleus cell }\end{array}$ & $\begin{array}{c}\text { Severe portal } \\
\text { congestion with } \\
\text { periportal cellular } \\
\text { infiltration by mono- } \\
\text { nucleus cell }\end{array}$ \\
\hline Spleen & $\begin{array}{l}\text { No visible } \\
\text { lesion }\end{array}$ & No visible lesion & No visible lesion & No visible lesion & No visible lesion & No visible lesion \\
\hline Testes & $\begin{array}{l}\text { No visible } \\
\text { lesion }\end{array}$ & No visible lesion & No visible lesion & No visible lesion & $\begin{array}{l}\text { No visible lesion. } \\
\text { Germinal epithelium } \\
\text { height reduced }\end{array}$ & $\begin{array}{l}\text { No visible lesion } \\
\text { marked sloughing of } \\
\text { the germinal } \\
\text { epithelium }\end{array}$ \\
\hline
\end{tabular}

TOLE $=$ Telfairia occidentalis Leaves Extract.
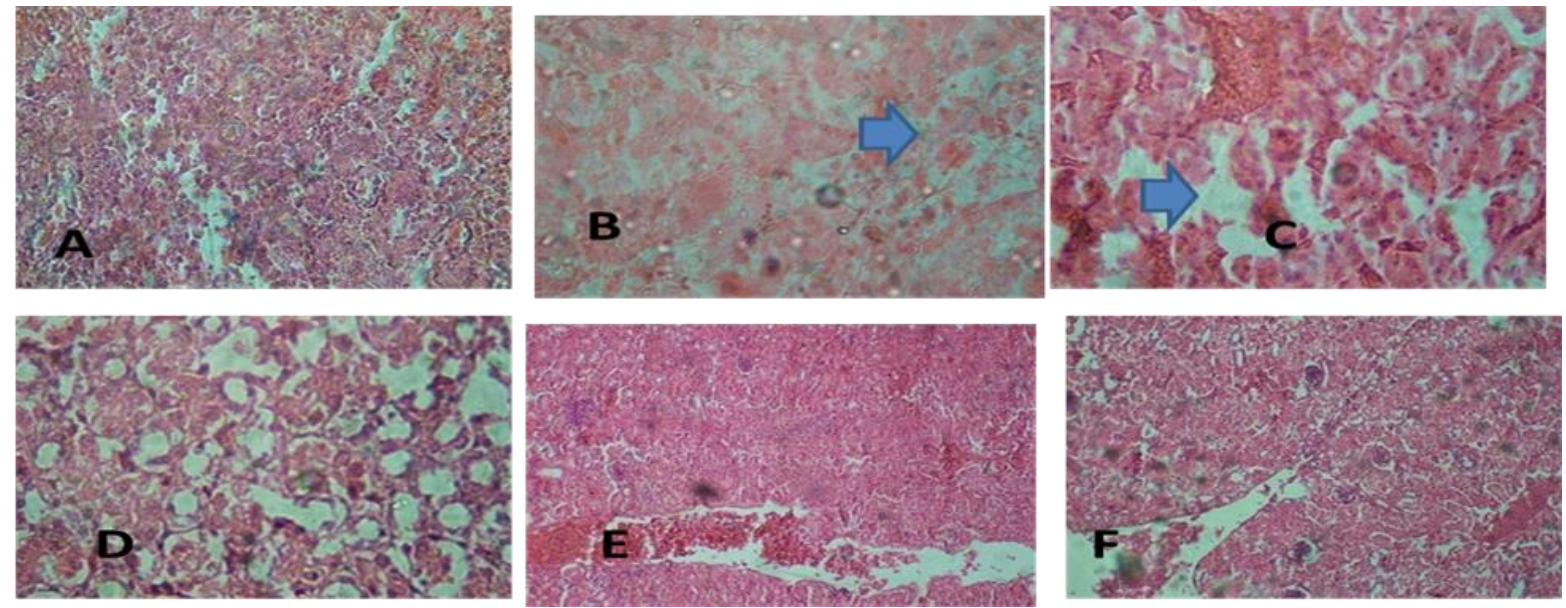

Figure 1. Micrographs of the kidneys of Nera black cocks served fluted pumpkin leaf extract at 4 weeks interval for 24 weeks $\mathrm{A}=0 \mathrm{~mL} / \mathrm{TOLE} / \mathrm{L}$ (no visible lesions seen). $\mathrm{B}=30 \mathrm{~mL} / \mathrm{TOLE} / \mathrm{L}$ (wide spread coagulative necrosis of the renal tubules (arrow); $\mathrm{C}=60 \mathrm{~mL} / /$ TOLE/L (severe generalized interstitial congestion), $\mathrm{D}=90 \mathrm{~mL} / \mathrm{TOLE} / \mathrm{L}$ (mild to moderate loss and sloughing of renal tubular epithelium), $\mathrm{E}=120 \mathrm{~mL} /$ TOLE/L (severe generalized interstitial congestion), F=150mL/ TOLE/L (widespread necrosis of the renal tubules. $(\mathrm{mg} \times 400)$
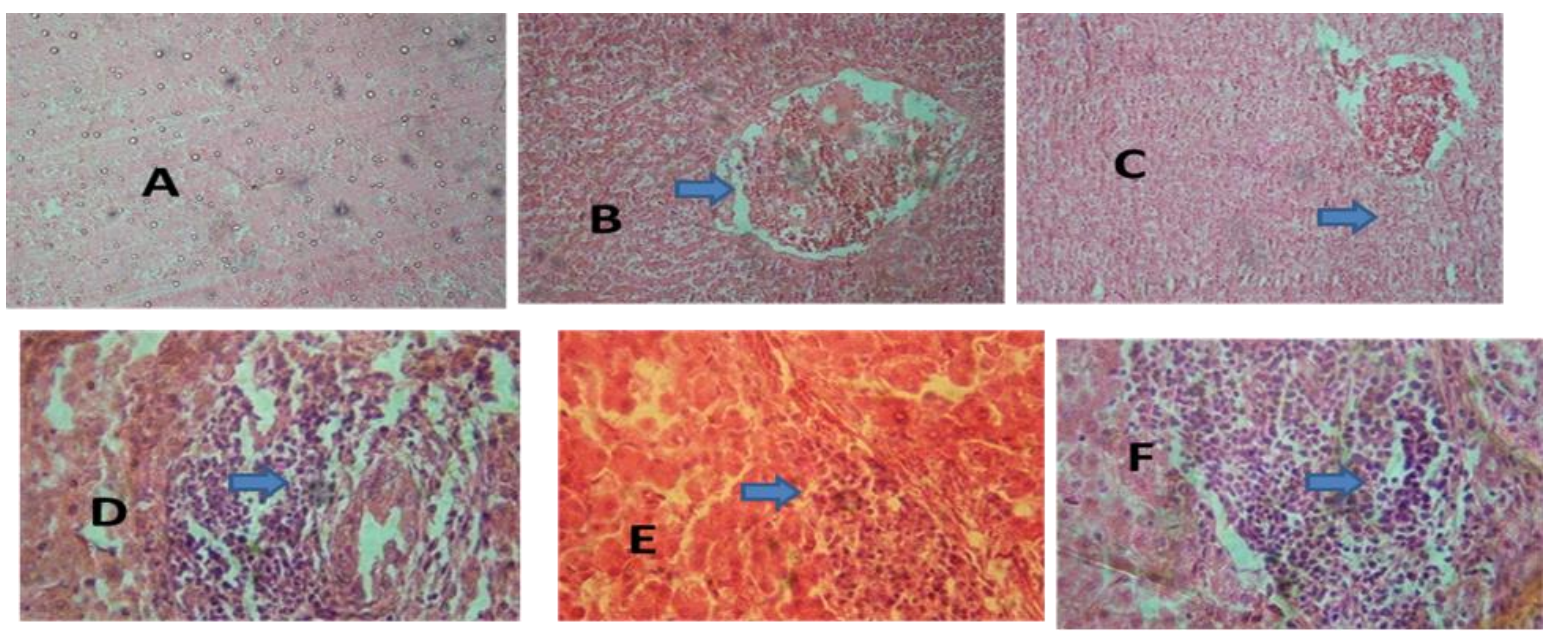

Figure 2. Micrographs of the liver of Nera black cocks served fluted pumpkin leaf extract at 4 week interval for 24 weeks. TOLE $=$ Telfairia occidentalis Leaves Extract. A: $0 \mathrm{~mL} / \mathrm{L}$ (No visible lesions seen), B: 30mL TOLE/L (Portal congestion (arrows), C: $60 \mathrm{~mL}$ TOLE/L (Severe central venous congestion), D: 90mL TOLE/L (Severe portal congestion with periportal cellular infiltration by mono-nuclear cells), E: $120 \mathrm{~mL}$ TOLE/L (Severe portal congestion with periportal cellular infiltration by mono-nuclear cells). F: 150mL TOLE/L (Severe portal congestion with periportal cellular infiltration by mono-nuclear cells) $(\mathrm{Mg} \times 400)$. 

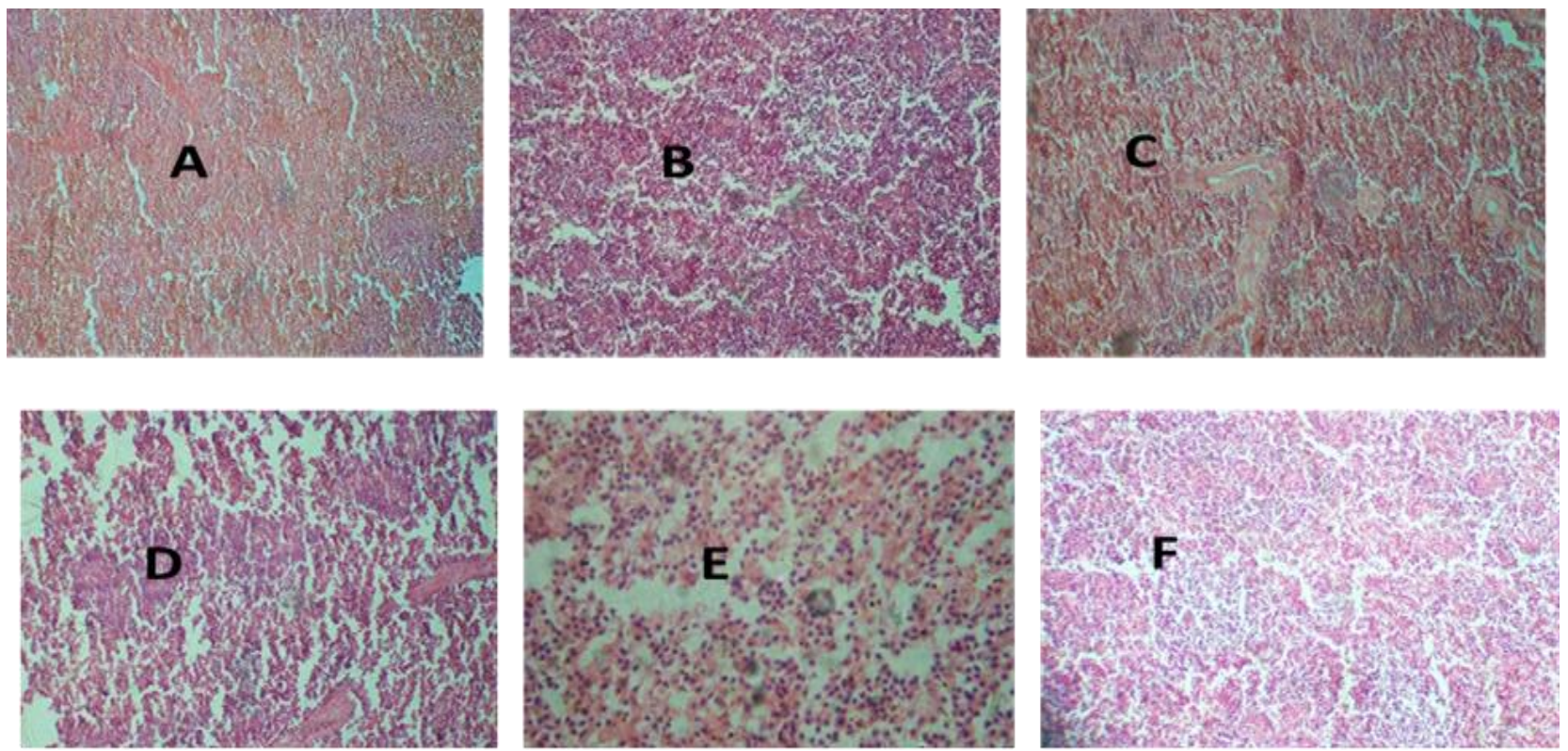

Figure 3. Micrographs of the spleen of Nera black cocks served fluted pumpkin leaf extract at 4 week interval for 24 weeks A to F: No visible lesions seen, $(\mathrm{Mg} \times 400)$. TOLE $=$ Telfairia occidentalis Leaves Extract. $\mathrm{A}=(0 \mathrm{ml} \mathrm{TOLE} / \mathrm{L}), \mathrm{B}=(30 \mathrm{~mL} \mathrm{TOLE} / \mathrm{L}), \mathrm{C}=(60 \mathrm{~mL}$ TOLE/L), $\mathrm{D}=(90 \mathrm{~mL}$ TOLE/L), $\mathrm{E}=(120 \mathrm{~mL}$ TOLE/L $), \mathrm{F}=(150 \mathrm{TOLE} / \mathrm{L})$
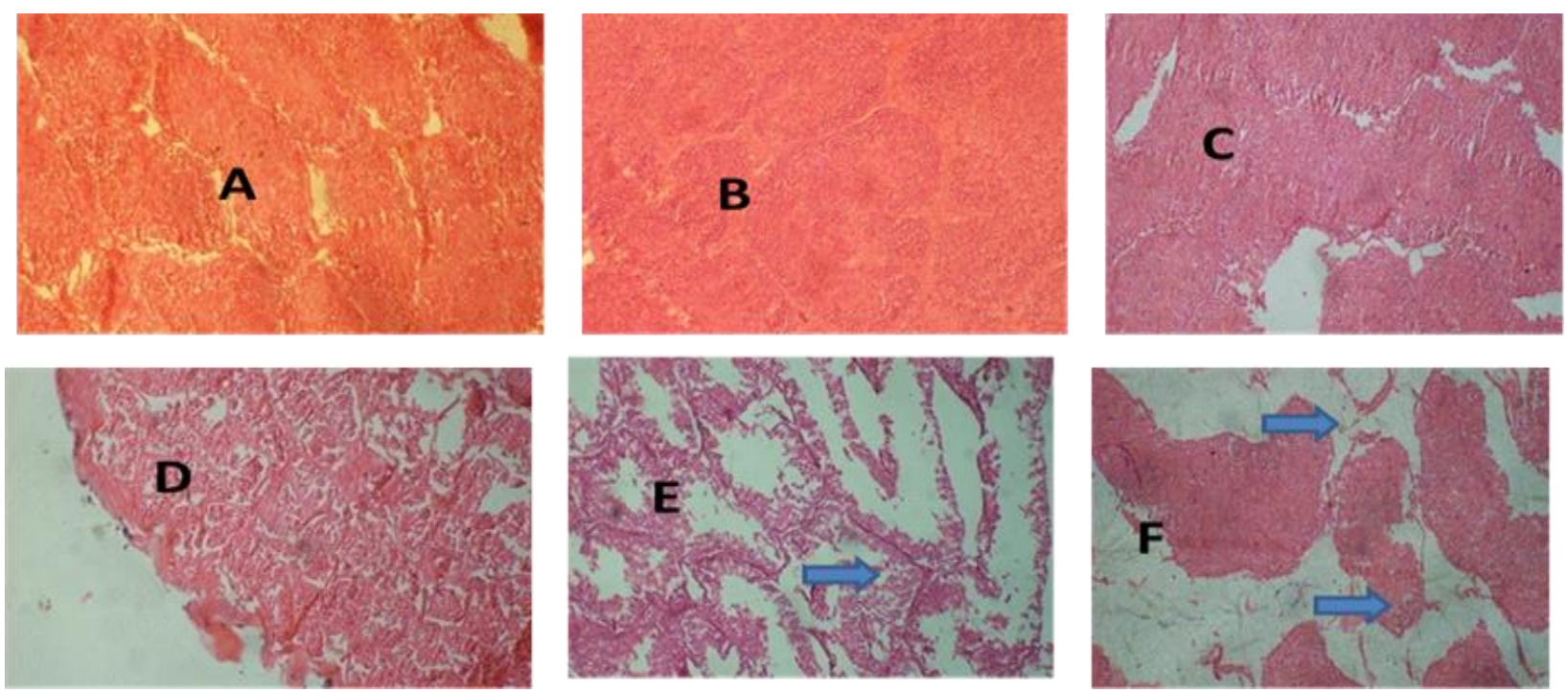

Figure 4. Micrographs of the testes of Nera black cocks served fluted pumpkin leaf extract at 4 week interval for 24 weeks A to D: No visible lesions seen, E and F: Marked sloughing of the Germinal Epithelium (arrows) $(\mathrm{Mg} \times 400)$. TOLE $=$ Telfairia occidentalis Leaves Extract. $\mathrm{A}=(0 \mathrm{ml}$ TOLE/L), $\mathrm{B}=(30 \mathrm{~mL}$ TOLE$/ \mathrm{L}), \mathrm{C}=(60 \mathrm{~mL}$ TOLE$/ \mathrm{L}), \mathrm{D}=(90 \mathrm{~mL}$ TOLE$/ \mathrm{L}), \mathrm{E}=(120 \mathrm{~mL}$ TOLE$/ \mathrm{L}), \mathrm{F}=(150 \mathrm{TOLE} / \mathrm{L})$

\section{DISCUSSION}

This study showed that the aqueous extract of the plant produced significant $(\mathrm{P}<0.05)$ increase in the levels of the $\mathrm{PCV}, \mathrm{Hb}, \mathrm{WBC}, \mathrm{MCV}, \mathrm{MCH}$ and monocytes when compared with the control. The best PVC (38.39\%) and $\mathrm{Hb}(12.79 \mathrm{~g} / \mathrm{dL})$ were obtained for birds served $60 \mathrm{ml} / \mathrm{l}$ TOLE while the least parameters $(35.20 \%$ and $11.73 \mathrm{~g} / \mathrm{dL}$ respectively) were obtained for birds on the control. This showed that animals suffering from low blood volume may benefit from the administration of this plant extract. This observation of increased level of erythron supports the earlier research findings that this plant has haematinic potency (Adedapo et al., 2002; Nworgu et al., 2007; Ifeanyi et al., 2014). The increase in the level of erythron produced by this extract may be due to the fact that the leaves of this plant are rich in many minerals (Burkill, 1994; Aletor et al., 1995; Archibong, 2002) high in crude protein, essential and non-essential amino acid in the leaf (Alabi et al., 2017; Fasuyi, 2007). This result agrees with 
Onyekwereh et al., 2019

the study of Alada (2000) and lends validity to the use of the leaves in the treatment of anaemia (Gbile, 1986). Birds on treatment $\mathrm{D}$ recorded the highest value of $13.92 \times$ $10^{6} / \mathrm{mm}$ for WBC though it was not significantly different $(\mathrm{P}>0.05)$ from the values obtained for birds on treatments $\mathrm{A}, \mathrm{C}$ and $\mathrm{F}$ but significantly different $(\mathrm{P}<0.05)$ from those on $\mathrm{B}$ and $\mathrm{E}$. The WBC helps to defend the body against foreign organism or extraneous materials so the higher the WBC the better the ability of animal to fight diseases since the WBC values fall within the normal range as reported by Mitruka and Rawnsley (1981), it then suggests that the health status of the birds was not challenged by the administration of this extract.

Birds on treatment $\mathrm{C}$ recorded the highest $\mathrm{MCV}$ $(142.48 \mu)$ value which was similar to the values obtained for birds on treatment $\mathrm{B}$ but different $(\mathrm{P}<0.05)$ from the values obtained for birds on treatments $\mathrm{A}, \mathrm{D}, \mathrm{E}$ and $\mathrm{F}$. The highest $\mathrm{MCH}$ value of $48.50 \mu \mathrm{g}$ was also obtain for birds on treatment $\mathrm{C}$ though it was similar to the values obtained for birds on treatments $\mathrm{A}$ and $\mathrm{D}$. The result obtained for the corpuscular constants in this study did not follow any particular trend and they were within the normal physiological range as reported by Mitruka and Rawnsley (1981) for normal cocks. The values obtained for the monocytes and eosinophils were significantly different but did not follow any particular pattern.

Serum biochemical investigations have been explored extensively to distinguish normal state from stress and diseased conditions in animals. Except for the albumin and AST, all other serum parameters investigated in this study were significantly $(\mathrm{P}<0.05)$ influenced by the administration of the TOLE.

The total protein, globulin and ALT increased with increasing levels of TOLE while triglyceride decreased with increasing levels of TOLE. The total proteins were higher for birds on the TOLE treatments than for birds on the control. This increase could be attributed to the additional protein supplied by the TOLE since the birds were on the same diets. This observation was similar to the report of Adedapo et al. (2008) and Alabi et al. (2017) who reported that aqueous extract of fluted pumpkin leaves caused a significant increase in the levels of the total protein and globulin of finisher broilers and rats respectively that were on fluted pumpkin leaves extract treatment. Although the albumin values in this present study were not significant ( $\mathrm{P}>0.05)$, Nworgu et al. (2007) reported an increase in the albumin levels of birds on treatment $\mathrm{F}(150 \mathrm{~mL} / \mathrm{L})$ having the values of $10.6 \mathrm{IU} / \mathrm{L}$. The slight increase in the serum enzyme activities suggest that there was little breakdown of muscle tissues on the birds on the TOLE treatments. The values of the triglycerides decreased with increasing levels of TOLE, this points to the ability of the extract to lower the lipids content as earlier reported by Adaramoye et al. (2007) and Nworgu et al. (2012).

Telfairia occidentalis leaves extract showed various cellular effects on histological characteristics of the tissues examined. The liver and kidney were the most affected while in the spleen and testes no lesion was observed. The hepatic lesion was characteristic by mild to severe portal congestion with periportal cellular infiltration by mononuclear cell and severe central venous congestion while the renal lesion were characterized by widespread coagulative necrosis of the renal tubule with generalized intestinal congestion and sloughing of renal tubular epithelium. This could be traced to the presence of alkaloids (Burkill, 1994) which have been observed with Telfairia occidentalis. This corroborates with the findings of Akubue et al. (1980) who reported venous congestion and in some cases burst vessels in the liver, spleen, lungs and heart of rats given aqueous extract of Telfairia occidentalis while Iweala and Obioda (2009) also reported irregularities in the liver of rats fed Telfairia occidentalis supplemented diet. Acute toxicity including hepatic toxicity have been reported (Akindele et al., 2018; Imosemi, 2018) in mice given Telfairia occidentalis up to $5000 \mathrm{mg} / \mathrm{kg}$ orally, with signs of decreased locomotion, calmness, writhing and increased breathing at higher doses of LD50 of intraperitoneal administration at 3000-5000 $\mathrm{mg} / \mathrm{kg}$. Although, there were no lesion observed in the testes in all the treatments, cocks on treatments $\mathrm{E}$ and $\mathrm{F}$ (120 and $150 \mathrm{~mL}$ TOLE/L) showed reduced germinal epithelium height and marked sloughing of the germinal epithelium respectively. The implication of this is disordered spermatogenesis and infertile/immature sperm cells. However, this effect is dose dependent since it was not observed at levels between 30-90 mL TOLE of water implying that, at higher doses of TOLE there was cell damage which could be detrimental to the fertility of cocks. This was similar to the findings of Adedapo et al. (2008) who reported testicular degeneration with severe disorganization of seminiferous tubules which were devoid of spermatic cells in rats served fluted pumpkin leaves extract. However, Iweala and Obioda (2009) reported the presence of large spermatogonia in the testes of rats fed Telfairia occidentalis supplemented diet while Nwangwa et al. (2007) reported a regenerative effect on the histology of rat's testes served the extract of fluted pumpkin leaves extract. Imosemi (2018); Sakpa et al. (2015) and Saalu et al. (2010) also testified to the 
testiculo-protective attributes of TOLE at lower doses up to $200 \mathrm{mg} / \mathrm{kg}$ in adult male Wister rats that showed increased sperm count, sperm viability and motility, enhanced spermatogenesis with elevated levels of testosterone and luteinizing and follicle stimulating hormones; but found aqueous TOLE to be testiculo-toxic at high dose of $800 \mathrm{mg} / \mathrm{kg}$ body weight of male Wister rat.

\section{CONCLUSION}

Long term supplementation of TOLE for cockerel production should not exceed $60 \mathrm{~mL}$ of TOLE per liter of water as the administration in excess of this can bring about tissue breakdown and reduced fertility. Animals suffering from blood loss can benefit from the administration of fluted pumpkin leaves extract as the extract increased erythron production.

\section{DECLARATIONS}

\section{Competing interests}

The authors declare that they have no competing interests.

\section{Author's contributions}

All the authors have made substantive contribution to the study from its design to implementation, collection of data, statistical analysis, writing reports and manuscript preparation.

\section{Consent to publish}

All the authors gave their informed consent prior to their inclusion in the study.

\section{REFERENCES}

Adaramoye OA, Achem J, Akintayo OO and Fafunso MA (2007). Hypolipidemic effect of Telfairia. Occidentalis (fluted pumpkin) in rats fed cholesterol -rich diet. Journal of Medicinal Food, 10: 330-336.

Adedapo, AA, Dina, AO, Saba AB and Oladipo OD (2002). Evaluation of Telfairia. Occidentalis and sorghum bicolor extracts as potent haematinies in domestic rabbits. Nigerian Journal of Animal Production, 29(2): 88-93.

Adedapo AA, Adenugba OA and Emikpe BO (2008). Effects of Aqueous extract of leaves of Telfairia occidentalis on rat's recent progress in medicinal plant vol. 20 Phytopharmacology and Therapeutic Values, 11: 385-395.

Akindele AJ, Oladimeji-Salami AJ, Oyetola RA and Osiagwu DD (2018). Sub-chronic toxicity of the hydroethanolic leaf extract of Telfairia occidentalis Hook. f. (Cucurbitaceae) in male rats. Medicines, 5(4): 1-22.

Akubue PI, kar A and Nucheita FN (1980). Toxicity of extract of roots and leaves of Telfairia Occidentalis. Planta medica, 38: 339-343.
Alabi O, Ayoola M and Akinoso O (2017). Performance characteristics and physiological Response of broiler chickens at finisher stage to oral Supplementation with fluted pumpkin, telfairia occidentalis leaf extract Journal of Central European Agriculture, 18(3): 646-656. DOI: 10.5513/jcea01/18.3.1938

Alada ARA (2000). The haematological effect of Telfairia occidentalis diet preparation. Journal of Biomedical Research, 3:185-186.

Aletor MVA and Adegun OA (1995). Nutrients and anti- nutrient composition of some tropical leafy vegetables. Food Chemistry, 53: 375-379.

Archibong EM (2002). Biochemical composition and biotoxicity of fluted pumpkin (Telfairia occidentalis), M.Sc Thesis, Department of Biochemistry, University of Calabar, Nigeria

Badifu, GI, Akpapunam MA and Mgbemere VM (1995). The fate of beta-carotene in processed leaves of fluted pumpkin (Telfairia Occidentals hook. F.): A popular veg. in Nigerian diet. Plants Foods Human Nutrition 48:141-147.

Burkill HM (1994). The useful plants of West Tropical Africa. Vol. Il, Royal Botanical Gardens, Kew, England.

Coles EH (1986). Veterinary clinical pathology 4th edition. W.B. Saunders Company, Philadelphia.

Disbrey BD and Rack JH (1970). Histological Laboratory Method. Livingstone, Edinburgh, pp. 56-128.

Drury RAB and Wallington EA (1967). Carleton's Histological Technique. 4th edition. Oxford University Press, London. Pp. 120-123.

Fasuyi AO (2006). Nutritional potential of some tropical vegetable leaf meal; chemical characterization and functional properties. African Journal of Biotechnology, 5: 49-53.

Fasuyi AO and Nonyerem AD (2007). Biochemical nutritional and haematological implication of Telfairia occidentalis leaf protein as protein supplement in broiler starter diets. African Journal of Biotechnology, 6: 1055-1063.

Gbile ZO (1986). Ethnobotany, Taxonomy and conservation of medicinal plants. In: The state of medicinal plants Research in Nigeria, Sofowora, A. (Ed.). University of Ibadan Press, Ibadan Nigeria.

Hunter KJ and Fletcher JM (2002). The antioxidant activity and composition of fresh, frozen, jarred and canned vegetables. Innovative Food Science and Emerging Technologies, 3: 399-406. https://ucanr.edu/datastoreFiles/608-638.pdf

Ifeanyi $\mathrm{OE}$, Ifeoma $\mathrm{CM}$, Ndubuisi OT, Nwakaego $\mathrm{OB}$ and Braxton AQ (2014) Haematological effects of fluted pumpkin (Telfairia occidentalis) leaves in rats. International Journal of Life Sciences, Biotechnology \& Pharma Research, 3(1): 172-182. http://www.ijlbpr.com/currentissue.php

Imoseni IO (2018) Review of the toxicity, medicinal benefits, pharmacological actions and morphological effects of Telfairia occidentalis hook. F. European Journal of Pharmaceutical and Medical Research, 6(7): 22-32.

Iweala EEJ and Obioda O (2009). Some biochemical, haematological and histological responses to a long term consumption of Telfairia occidentalis - supplemented diet in rats. Pakistan Journal of Nutrition, 8: 1199-1203. 
Jain NC (1986). Veterinary clinical pathology. Lea and Fabiger Philadelphia U.S.A., pp.15-81.

Jimoh TO (2018). Enzymes inhibitory and radical scavenging potentials of two selected tropical vegetables (Moringa oleifera and Telfairia occidentalis) leaves relevant to type 2 diabetes mellitus. Brazilian Journal of Pharmacognosy, 28: 73-79.

Kohn RA and Allen MS (1995). Enrichment of proteolysis activity relative to nitrogen in preparations from the rumen for invitro studies. Animal Feed Science and Technology, $52: 1-4$.

Mitruka BM and Rawnsley HM (1981). Clinical biochemical and haemotolgoical reference values in normal experimental animals and normal humans second edition. New York: Masson Publishing.

Nneka VC (2006). Potentials of the leaf extract of Azadriachta indica, A. Juss and Ocimum gratissimum L. for the control of some potato fungal diseases. Nigerian Journal of Botany, 19 (1): 69-73.

Nwangwa EK, Mordi J, Ebeye OA and Ojieh AE (2007). Testicular regenerative effects induced by the extracts of Telfairia occidentalis in rat. Caderno de Pesquisa, Series Biologia, 19: 27-35.

Nworgu FC, Ogunbenro SA and Soles KS (2007). Performance and some Blood chemistry indices of Broiler chicken served fluted pumpkin (Telfairia occidentalis) leaves extract supplement. American-Eurasian. Journal of Agriculture and environmental Science, 2(1): 90-95.

Nworgu FC, Oduola OA, Aderemi FA and Taiwo OO (2008). Some haematological and serum biochemistry indices of broiler chickens served heat treated fluted pumpkin
(Telfairia occidentalis) leaves extract supplement. Journal of Agriculture and Rural Development, 2: 94-107.

Nworgu FC, Akintola KA, Njorku OD, Omosowom BC, Ozor PL, Olatidoye OP and Adekola AG (2012). Performance of pullet chicks served fluted punpkin (Telfairia occidentalis) leaves extract supplement and the effects on their blood parameters. European Journal of Scientific Research, 87(2): 270-282.

Oboh G, Nwanna E and Elusiyan C (2010). Antioxidant and antimicrobial properties of Telfairia occidentalis (Fluted pumpkin) leaf extracts. Journal of Pharmacology and Toxicology, 5(8): 539-547.

Pauzenga U (1985). Feeding parent stock. Zootecnia international December, 1985. Pp. 22-24.

Peters T, Biamonte GT and Doumas BT (1982). Protein (total protein) in serum. In: Selected methods of clinical chemistry. Faulkner, G.W.R. and Mcites, S. (Eds) American Association for Clinical Chemistry, pp. 100-115.

Saalu LC, Kpela T, Benebo AS, Oyewopo AO, Anifowope EO and Oguntola JA (2010). The dose-dependent testiculoprotective and testiculotoxic potentials of Telfairia occidentalis Hook f. leaves extract in rat. International Journal of Applied Research in Natural Products, 3(3): 2738.

Sakpa LC, Onovughakpo-Sakpa OE and Okhimamhe AF (2015). Profertility effects of aqueous leaf extract of Telfairia occidentalis in adult male wistar rats. Journal of Experimental and Clinical Anatomy, 4(2): 88-94.

SAS Institute Inc, (1999). SAS/STAT User's Guide-Version 8 for windows SAS Institute Inc. SAS Campus Drive, Cary, North Carolina, U.S.A. 